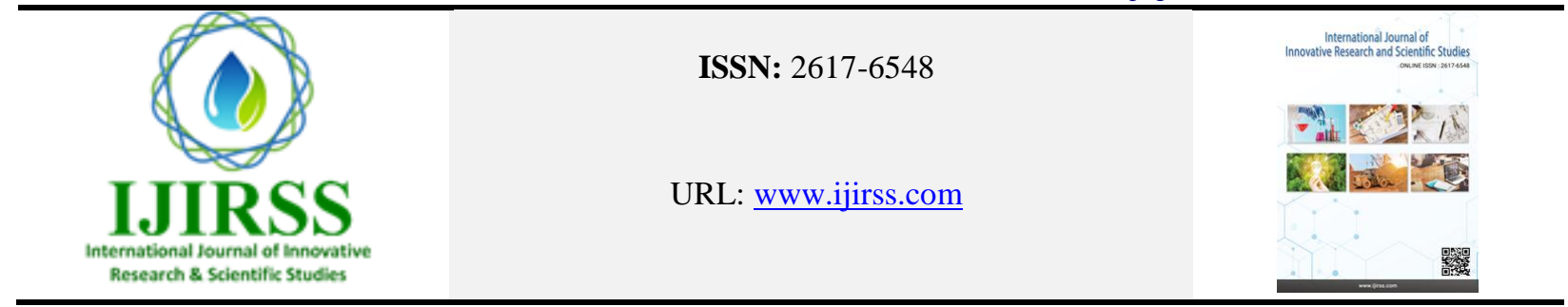

\title{
Milk and Marketing of Dairy Productions in Samangan Province: A Case Study in Districts of Khuram-Sarbagh, Feroz-Nakhchir, and Center of Samangan (Aybak), Afghanistan
}

\author{
Abdul Hadi Mukhtar ${ }^{1}$, Sayed Batin Ashkar²*, Benazir Azizi ${ }^{3}$
}

\begin{abstract}
${ }^{1}$ Agricultural Economics and Extension Department, Faculty of Agriculture, Samangan Higher Education Institute, Aybak 2001, Afghanistan, Hadimukhtar91@ gmail.com

${ }^{2}$ Agricultural Economics and Extension Department, Faculty of Agriculture, Samangan Higher Education Institute, Farkhar3752, Takhar, Afghanistan, *Corresponding Author: sayedbatin1@gmail.com

${ }^{3}$ Agricultural Economics and Extension Department, Faculty of Agriculture, Samangan Higher Education Institute, Aybak 2001, Afghanistan, benazirazizi831@gmail.com
\end{abstract}

*Corresponding author: Sayed Batin Ashkar (sayedbatin1@gmail.com)

\begin{abstract}
In this study the status of milk and dairy production marketing in Samangan province is explained. Locking of ranchers accessing to a respondent dairy production market is the main problem focused herein. In Afghanistan illiteracy, traditional customs dominance and low economy level are the major gaps somewhat nationally remained unresolved among most of ranchers. The main objective of this study is assessing the dairy productions market situation to empower the economy level of farmers. A complex method was applied in this study including observation, interview, and questionnaire. Totally 117 questionnaires were handled. Results of analyzed collected data clarify that $90 \%$ of ranchers were illiterate, dairy cattle keeping is more than other milky animals because of its lower needs to silage and land. It has been concluded that farmers of Samangan province have adequate experience of keeping and nourishing the domestic animals in order to get a noticeable income. For getting the highest income and having modernized dairy production activities, from the viewpoint of authors, gradually researches accommodating are recommended and this research findings and conclusions will contribute better designing of the future researches.
\end{abstract}

Keywords: Dairying, Rancher, Marketing channels, Aybak, Dairy cattle.

DOI: $10.53894 /$ ijirss.v4i3.70

Funding: This study received no specific financial support.

History: Received: 31 January 2021/Revised: 16 April 2021/Accepted: 20 April 2021/Published: 3 May 2021

Licensed: This work is licensed under a Creative Commons Attribution 4.0 License (c) EY 3

Acknowledgement: All authors contributed to the conception and design of the study.

Competing Interests: The authors declare that they have no conflict of interests.

Transparency: The authors confirm that the manuscript is an honest, accurate, and transparent account of the study was reported; that no vital features of the study have been omitted; and that any discrepancies from the study as planned have been explained.

Ethical: This study follows all ethical practices during writing.

\section{Introduction}

Food choice decision in viewpoints of consumers is a complex subject and contain the situational, egoistic and altruistic motivations [1] as well, environmental cleanliness, appropriateness of feeding, well stockman-ship, abundance of pasture, etc. [2]. Among dairy productions milk is one of the most important and valuable sources of food around the globe 
especially in Afghanistan that most of its residents directly or indirectly engage in livestock and agriculture in order to provide their prior dairy products necessities [1,2]. Major opportunities exist to address improved dairy production in Asian countries like China, South-East Asia, etc. in which not only increasing individual animal productions, but also postproduction system, dairying and other marketing issues which are associated with organized dairy production require addressing [3]. Animal protein producing thorough dairy cattle necessitates less land and silages amongst the other lacteal animals [4] such as goat, sheep, and cow. So, most of ranchers and typical householders prefer to keep one or more than one dairy cattle aiming to get dairy products. Due to not activating the collecting cooperatives of milk and processing companies a little amount of produced milk is consumed directly by families. Whereas the surplus amount is changed to yogurt, cheese, cream, dried curd, etc. by ranchers' families [5]. Diary productions especially milk supplying places require providing the precautionary hygienic facilities otherwise its rapidly changeable nutritious and valuable components like fat increase the spoilable traits and jeopardize its preservation conditions and transportation [6]. Although, majority provinces of Afghanistan especially Samangan has sufficient postural areas but its animal productions like milk and other dairy products are not produced satisfactorily [7]. As mentioned earlier, every family have one or two dairy cattle and get much precious products, but for the reasons of not being notified from the modern and newest methods of advantageous and economic ranching, and not existing of arranged marketing system their dairy productions are mostly sold in the villages and close places of their farms in the lowest price [5]. On the other hand, due to existence of the sufficient resources and its favorability in agriculture and livestock nourishing most of Samangan province householders engaged in these activities. Around Samangan province the Non-Governmental Organizations (NGOs) like GIZ have been performing many fundamental activities since 2001 such as reforming of dairy cattle in most districts of this province, medicating of various diseases, donating and assisting the related cooperatives, creating marketing programs to ranchers, etc. [8]. Regardless of them, there has not been done any specific research to evaluate the situation of dairy productions in Samangan province. Therefore in this study it is aimed to conduct the subject and to fill-out the related gaps. After conducting the research it has been found that farmers do not have a supportive source to provide their immediately financial needs in order to orient other relevant dairy production marketing activities. It is suggested that researches must be accommodated on how status of dairy productions especially marketing will be made better? Which commercial policies and strategies should be taken place? And other relating subjects. The results of this research will be a good resource and contribute better conducting of the future studies.

\section{Research Methodology}

In this study, questionnaire, interview and observation with relevant individuals were conducted. In the first step three places: center of Samangan (Aybak) and the districts of Feroz- Nakhchir and Khuram-Sarbagh were selected. In the second step, 27 villages as sample places were distinguished amongst three mentioned places. In Aybak, the villages of: Choghi, Gul-Qushlaq, Soofi-Qalaa, Joy-Zundan, Acha-Maili, Ayraghli, Aynacha, Dara-Jovandon, Mangtash-Bala; in KuhramSarbagh these villages: Habash, Khadriyan, Dah-Kalan, Dah-Now-Khuram, Abdul Malik, Habash-Khuram, Khaja Qushqar-Pain, Pasi-Hisar, Chahar-Sang; and in Feroz Nakhchir the villages of Dara-Afghania, Lab-Aab-Pain, Gunbatan, Malikan-Markaz, Sayed Aabad, Dara, Oozan, Asmail Khel, and Zilzila Aabad were selected. In this study 195 head of dairy cattle that 28 heads of them were agricultural including the F1, F2 and F3 generations and 167 heads were local varieties, 3719 sheep head and 1761 goats head were examined. Totally 117 questionnaires carried out on ranchers, personals of agriculture and livestock, and pertaining cooperatives in the sample areas Table 1 in which most of respondents were from Aybak and the minimum respondents were from Khuram-Sarbagh district.

Table-1.

Respondents in the sample areas

\begin{tabular}{l|l|l|l}
\hline & & \multicolumn{2}{|l}{ Sample places } \\
\hline & $\begin{array}{l}\text { Aybak } \\
\text { City }\end{array}$ & $\begin{array}{l}\text { Khuram- } \\
\text { Sarbagh }\end{array}$ & $\begin{array}{l}\text { Feroz } \\
\text { Nakhchir }\end{array}$ \\
\hline Respondents & 60 & 27 & 30 \\
\hline
\end{tabular}

\section{Results and Discussions}

Findings of this research show that in Samangan province the young, middle and old classes of householders directly or indirectly engage in livestock, as it is determined in Table 2 even 80 years-old individuals do this job. But, most of individuals who engage in this activity are 45 years. Averagely, about 4\% (5) of respondents were literate. Whereas, more than $90 \%$ of them were illiterate. Therefore, they could not be easily trained and taught the new scientific methods and getting their satisfaction is very difficult even impossible in major subjects.

The minimum and maximum family members of participants were 2 and 26 persons respectively. Most of the respondents' family member was 8 persons that desire keeping animal to provide their primitive necessities. Even families without land, keep and nourish many heads of dairy cattle, sheep or goat. Intermediately the respondents have a 20 years' experience of approaching this occupation Table 2 .

In the research areas it has been found that there are different sources of householders' income in which agriculture and livestock play an incomparable role among other sectors. Agriculture and livestock form about $90 \%(51.22+38.45) \%$ of total income while business and other sectors role is less than $10 \%$ Table 3 . 
Table-2.

Demographical characteristics of respondents

\begin{tabular}{|c|c|c|c|c|c|}
\hline \multirow[b]{3}{*}{ Statistical measures } & \multicolumn{5}{|c|}{ Demographical traits } \\
\hline & \multirow{2}{*}{ Age } & \multirow{2}{*}{ Literacy } & \multirow{2}{*}{ Family Member } & Land amount & Experiment \\
\hline & & & & (acre) & (year) \\
\hline Average & 46 & 5 & 10 & 11 & 20 \\
\hline Maximum & 80 & 16 & 26 & 150 & 80 \\
\hline Minimum & 20 & 0 & 2 & 0 & 1 \\
\hline Mode & 45 & 0 & 8 & 5 & 20 \\
\hline
\end{tabular}

Table-3.

Income sources in the research area

\begin{tabular}{l|l|l|l}
\hline Income sources & \multicolumn{3}{|l}{ Contribution in total income } \\
\hline Agriculture & & & $51.22 \%$ \\
\hline Livestock & & & $38.45 \%$ \\
\hline Business & & & $7.40 \%$ \\
\hline Other & & & $2.80 \%$ \\
\hline
\end{tabular}

However, the sheep and goat numbers are much more in the comparison with dairy cattle (3719 head sheep, 1761 head goat and 195 head dairy cattle) Table 4 in the research area, dairy cattle production is examined because of requiring less land and silages amongst the other lacteal animals [4] and difficulties in examining each head of them (sheep or goat).

Table-4.

Observed animals in the sample places

\begin{tabular}{l|l|l|l}
\hline & & Sample places & \\
\hline Observed animal & Aybak city & Khuram-Sarbagh & Feroz Nakhchir \\
\hline Dairy cattle & 90 & 57 & 48 \\
\hline Sheep & 2575 & 816 & 328 \\
\hline Goat & 617 & 816 & 328 \\
\hline
\end{tabular}

Besides those positive points the produced milk from dairy cattle provides a remarkable contribution on gross national income (GDI) of residents (average contribution is 34586 AFN) Table 5. Householders' maximum dairy cattle are 4 and minimum 1 head. Medially, per family 24hrs. milk consumption is 3 liters while maximum surplus amount of householders' daily produced milk is 33 liters. The average price per liter is 26AFN and it can be changed based on seasons and amount of milk in the market Table 5.

Table-5.

General information related to dairying and marketing of milk

\begin{tabular}{l|l|l|l}
\hline Measure type & Ave. & Max. & Min. \\
\hline Dairy cattle & 2 & 4 & 1 \\
\hline 1 head milk amount /24hrs. & 8 & 25 & 2 \\
\hline Consumption/24hrs. & 3 & 22 & 0 \\
\hline Surplus/24hrs. & 7 & 33 & 0 \\
\hline Price/liter (AFN) & 26 & 50 & 0 \\
\hline GDI/lactation (AFN) & 34586 & 198000 & \\
\hline
\end{tabular}

Results of the research shows that $65 \%$ of ranchers sell and supply their dairy products as raw milk, $23 \%$ as yogurt, $4,2 \%$ as cream, $5,8 \%$ as cheese and $1.6 \%$ as dried-curd. Average price of cheese per kg is $230 \mathrm{AFN}$ that shows the highest price amongst dairy products whilst average price of raw milk per liter is the lowest (25AFN). The inexpensiveness of raw milk attracts the attention of consumers to prefer it $\underline{\text { Table } 6 .}$.

Table-6.

Selling methods and price of dairy products

\begin{tabular}{l|l|l|l|l}
\hline Product & Rancher & Max. P & Min. P & Ave.P \\
\hline Raw-milk & $65 \%$ & 32 & 18 & 25 \\
\hline Yogurt & $23 \%$ & 50 & 20 & 35 \\
\hline Cream & $4.2 \%$ & 250 & 200 & 225 \\
\hline Cheese & $5.8 \%$ & 250 & 210 & 230 \\
\hline Dried-Curd & $1.6 \%$ & 110 & 80 & 95 \\
\hline
\end{tabular}


There are different buyers groups that directly enter to the dairy products markets around Samangan. As shown in Figure1, the selling channels are constituted from cooperatives, local-collectors, big-sellers, small-sellers, restaurants, icecream cookers and final consumers.

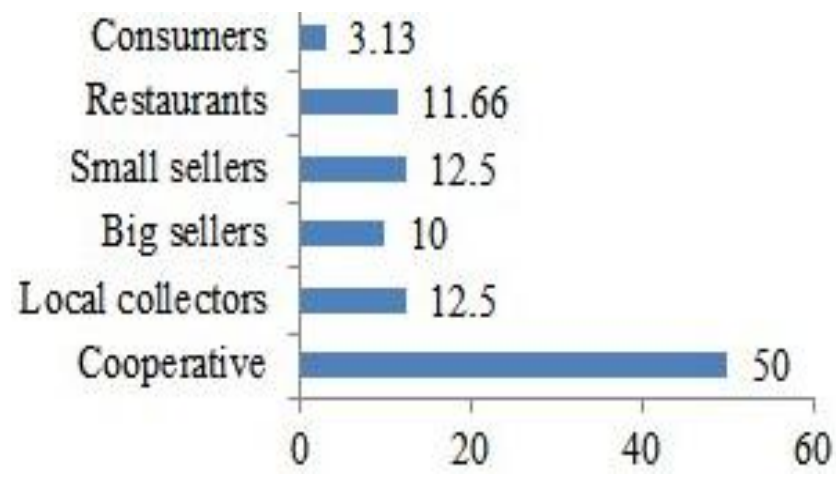

Figure-1.

Selling channels of dairy products

$50 \%$ of produced milk is sold to cooperatives, $12.5 \%$ to local collectors, $10 \%$ to big sellers, $12.5 \%$ to small sellers, $11.66 \%$ to restaurants and ice-cream cookers, and $3.13 \%$ to final consumers Figure 1.

There are many problems preventing livestock sector in Samangan province. Locking of market to sell the products when it is produced and requires selling and consuming. The percentage of this problem in Aybak irrespective of being center of the province is more than the sample districts (49\% in Aybak, 33\% in Feroz Nakhchir and 18\% in KhuramSarbagh). Processing of milk products is in a better situation in Aybak than the sample districts (in Aybak 24\%, KhuramSarbagh $49 \%$ and Feroz-Nakhchir 27\%). The problems vary based on being far or close to center of the province. KhuramSarbagh is farther than Feroz-Nakhchir from center of Samangan. So, the percentage of problems are more in this district (processing 49\%, Selling 51\%, and credit shortage 36\%) than Feroz-Nakhchir which is closer to the center of Samangan Province than Khuram-Sarbagh and percentages of the mentioned problems in this district is $27 \%, 10 \%$, and $15 \%$ respectively Table 7.

Table-7.

Problems of dairy products marketing

\begin{tabular}{l|l|l|l}
\hline Problem type & Aybak & Khuram- Sarbagh & Feroz- Nakhchir \\
\hline Market locking & 49 & 18 & 33 \\
\hline Credit shortage & 49 & 36 & 15 \\
\hline Transportation & 27 & 29 & 43 \\
\hline Learning courses & 43 & 23 & 35 \\
\hline Instruments locking & 26 & 29 & 44 \\
\hline Selling price & 38 & 51 & 10 \\
\hline Milk processing & 24 & 49 & 27 \\
\hline
\end{tabular}

\section{Conclusion}

The majority of livestock-holders do not have access to the markets in order to sell their dairy productions in a suitable price to respond consumption costs and other related necessities. It has been concluded that $73 \%$ of the ranchers do not have access to the markets and $11 \%$ have, $11 \%$ of them sell their dairy productions to cooperatives and $5 \%$ to restaurants and ice-cream cookers. Most of farmers feed their animals by wheat-straw (42\%) as the first food, secondly forage (24\%) and in the third degree oilcake and condensed foods (31\%). Dairy productions are sold variously containing raw-milk, yogurt, cream, etc. to local collectors, cooperatives, big sellers, small sellers, ice-cream- cookers, restaurants and offices. Raw-milk average price is $25 \mathrm{AFN} /$ liter that $65 \%$ of respondents sell and supply in that price. In this province there is just one processing factory of dairy products with capability of 1200 liter/day in order to change it and to produce yogurt, whey, curd, butter, cream and cheese. Around the country, as other importing commodities extensively dairy-products importing from many countries including Pakistan, Iran, China, Uzbekistan, India, etc. negatively affects on domestic consumers' interests that by seeing a bit difference in appearance of foreign products they commonly prefer using of them more than domestic ones. Unfortunately, this is a generic fact applicable in all importable goods. Inaccessibility to transportation means, locking of respondent markets, credit systems, educational programs, hygienic conditions, processing centers, etc. are the major unresolved problems relevant to this subject necessitate conducting future researches. Fortunately, this study conclusion can be a good reference and academically and methodologically will contribute accommodating of relevant studies in the future. 


\subsection{Suggestions}

1. Designing new commercial rules and policies in Samangan province.

2. Establishing quality control administration.

3. Providing the private sectors persuasive programs in order to invest in producing and processing of animalproductions.

4. Establishing an influential finance system in Samangan province to support ranchers permanently.

5. Creating marketing information system and producing of dairy-products based on market demands.

\section{Reference}

[1] R. Weinrich, S. Kühl, A. Zühlsdorf, and A. Spiller, "Consumer attitudes in Germany towards different dairy housing systems and their implications for the marketing of pasture raised milk," International Food and Agribusiness Management Review, vol. 17, pp. 205-222, 2014.

[2] K. Ellis, K. Billington, B. McNeil, and D. McKeegan, "Public opinion on UK milk marketing and dairy cow welfare," Animal Welfare, vol. 18, pp. 267-282, 2009.

[3] M. Saadullah, "Smallholder dairy production and marketing: Opportunities and constraints," in Proc. a South-South Work. Held Natl. Dairy Dev. Board Anand, India, 13-16 March 2001, 2001, pp. 414-430.

[4] F. Parwiz, Principles of dairy cattle nourishment vol. 7. Tahran: Jihad Publ. Univ. Aromia, 1997.

[5] Z. Zia, Animal nourishment. Kabul: Nuamani Publication, 2016.

[6] A. Nor-Muhammad, Milk production and its marketing in Kapisa Province. Afghanistan, Kabul, 2016.

[7] R. Muhammad Hassan, Dairy cattle nourishment. Kabul, 2016.

[8] SAD, Management of Livestock, Milk processing and marketing: Aybak, 2016. 